\title{
The Sand Rat (Psammomys Obesus) as an Experimental Animal in Studies of Diabetes Mellitus*
}

\author{
Donald B. Hackel, Emeen Mikat, Harold E. Lebovitz, Knut Sonmidt-Nielsen, Edward S. Horton, \\ and Thomas D. KinneY
}

Departments of Pathology, Medicine and Zoology, Duke University, Durham, North Carolina, U.S.A.

Summary. The sand rat has some unique attributes, which make it a valuable experimental animal. The occurrence of increased plasma insulin levels and of hyperglycemia is linked to an increased food intake. As in the human maturity-onset type diabetes, there seems to be an element of insulin resistance, and this can be demonstrated in vitro by the relative unresponsiveness of sand rat adipose tissue to increasing doses of pork insulin. Prophylactic treatment with acetohexamide seems to have some protective effect against the diabetogenic results of a high calory diet. - It is expected that the diabetic syndrome in sand rats, which can be so easily induced by dietary manipulation, will be a valuable tool in helping to clarify some of the possible mechanisms in the syndrome of diabetes mellitus.

Le rat des sables (Psammomys obesus) en tant qu'animal expérimental pour l'étude du diabète sucré.

Résumé. Certaines caractéristiques particulières du rat des sables en font un animal d'expérience de grande valeur. L'augmentation des taux plasmatiques d'insuline et de glucose est liée chez lui à une augmentation de la prise de nourriture. Tout comme c'est le cas pour le diabète humain de type adulte, il semble y avoir participation d'un élément de résistance à l'insuline qui peut être mis en évidence in vitro par la sensibilité diminuée du tissu adipeux du rat des sables à l'insuline de porc. $\Pi$ semblerait qu'un traitement prophylactique par l'acétohexamide exerce un effet protecteur contre l'effet diabétogène d'un régime riche en calories. - Il semble raisonnable de penser que le syndrome diabétique du rat du sable, si facilement provoqué par la modification du régime, pourrait s'avérer être un instrument de grande valeur dans l'étude des mécanismes pathogénétiques possibles du syndrome diabétique.

Die Sandratte (Psammomys obesus) als experimentelles Modell zur Untersuchung des Diabetes mellitus.

Zusammenfassung. Die Sandratte verfügt über mehrere einmalige Eigenschaften, die aus ihr ein wertvolles Laboratoriumstier machen. Das häufige Auftreten von erhöhtem Plasma-Insulinspiegel und Hyperglykämie steht im Zusammenhang mit einer gesteigerten Nahrungsaufnahme. Wie im menschlichen Reife-Diabetes scheint auch hier eine Insulinresistenz aufzutreten, und diese ist in vitro nachweisbar: das inkubierte Fettgewebe der Sandratte spricht auf eine Stimulierung mit steigenden Dosen von Schweineinsulin nur wenig an. Prophylaktische Behandlung mit Acetohexamid deutet auf eine Schutzwirkung gegen die diabetogenen Folgen einer kalorienreichen Diät. - Es ist zu erwarten, daß das diabetische Syndrom in der Sandratte, das so leicht durch Manipulationen der Diät erzeugt werden kann, ein nützliches Modell zur Untersuchung der möglichen Mechanismen der diabetischen Pathogenese darstellen wird.

Key-words: Spontaneous diabetes, Sand rat, Psammomys obesus, Insulin in plasma, Insulin resistance, Acetohexamide, Diet and diabetes, Nutrition and diabetes, Obesity, Pancreas, Infections, Adipose tissue in vitro.
The sand rat has aroused particular interest as an experimental animal because of an apparent similarity to certain human diabetes-prone populations. As pointed out by NEEL [14] and by CAHILL [2], the metabolic alterations of diabetes mellitus could have survival value in times of inadequate food supply. Studies of various human population groups are, in general, consistent with this hypothesis $[1,4,3]$. In a similar fashion the sand rat in its natural habitat has a food supply that is of relatively low caloria content, requiring the intake of large quantities of plants in order to reach a bare subsistence level. Thus, it may have evolved with incipient diabetes as a mechanism that

* This work was carried out during the tenure of Research Career Awards from the U.S. Public Health Service to Drs. HACKel (HE-K6-14, 188) and SchMmDTNIELSEN, (K6-GM-21, 522) a Career Development Award to Dr. Lebovitz (K3-AM-17, 954), and a Research Fellowship to Dr. Horton (F3-AM-32, 326); supported by grants from the U.S. Public Health Service (AM-08949, AM-1324, and HE-0228), Eli Lilly Co., the Duke University Research Council, and the Mary Duke Biddle Foundation. is protective against the vagaries of desert food supplies.

When the sand rat was introduced to the affluent life of the laboratory and given a supply ad libitum of Purina Laboratory Chow, it was found to have overt manifestations of diabetes mellitus, including cataracts, glucosuria and hyperglycemia $[15,10]$. On the other hand, if the animals were maintained on an allvegetable diet of spinach, carrots and beets they did not show these effects.

Relation of caloric intake and glucose intolerance

When sand rats were switched from their usual all vegetable diet to a diet of higher caloric value (either Purina Laboratory Chow or a similar synthetic diet) they did not respond in a uniform manner [7, 8]. Some developed a fulminating type of diabetes, others were relatively resistant, and others were able to compensate for a while but eventually developed a progressive loss of glucose tolerance. An example of the fulminating type is seen in Figure 1, which demonstrates the almost complete loss of glucose tolerance and low plasma in. sulin levels in this group. At autopsy the pancreatic 
beta cells of these animals were degranulated and vacuolated, and they had fatty livers and glycogen nephrosis. They are probably similar to those found by Mrkr et al. to have severe diabetes and a low pancreatic insulin content [13]. It is of course possible that they had an initially high plasma insulin in the 2 weeks preceding the first analysis; and that the terminal picture was one of insulin exhaustion. Fig. 2 represents the

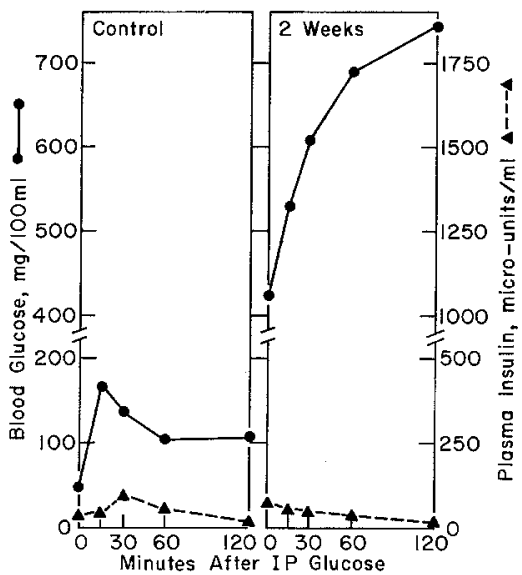

Fig. 1. Glueose tolerance test of sand rat with fulminating diabetes mellitus; on vegetable diet during control period (block on left); on Laboratory Chow for 2 weeks (block on right). From Diabetes 15, 109 (1966) [7]

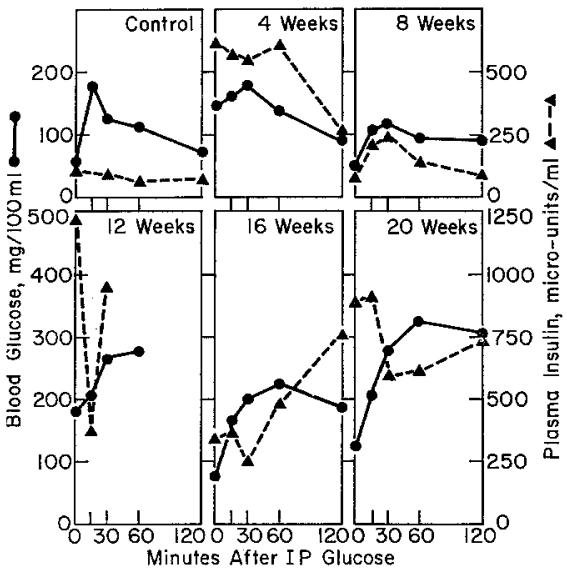

Fig. 2. Glucose tolerance test of sand rat on synthetic diet, with a variable but progressive course. From Diabetes 15, 110 (1966) [7]

type of response seen in most other animals: on the high calory diet the plasma insulin level was usually high, and the glucose tolerance was variably but progressively decreased.

In order to delineate further the relationship between food intake and glucose tolerance, groups of sand rats were subjected to shifts from low to high or from high to low caloric diets [6]. When animals were fed on a synthetic diet of restricted caloric content (average 29 calories/day) they lost weight, maintained normal glucose tolerance, and had a low plasma insulin (average $=22 \mu \mathrm{U} / \mathrm{ml}$ ). Shifting to a supply ad libitum of the same food, their daily food intake equalled 49 calories, their glucose tolerance became moderately decreased, and their plasma insulin levels increased markedly (average $=333 \mu \mathrm{U} / \mathrm{ml}$ ). Animals that were maintained at first on a diet ad libitum averaged 40 calories intake/day, developed loss of glucose tolerance and an elevated plasma insulin (av. $=822 \mu \mathrm{U} / \mathrm{ml}$ ). When their food intake was restricted to 28 calories/day they lost weight, and their glucose tolerance and plasma insulin levels (av. $=156 \mu \mathrm{U} / \mathrm{ml}_{\text {. }}$ ) became more normal.

Although these experiments speak strongly for the importance of overall calory content in the induction of diabetes, it is also possible that a particular component in the diet could be the main factor. For example, in the diet restriction studies, total calories were reduced by $30-40 \%$; and although carbohydrate intake was maintained in the same percentage relation to total calories, it was reduced in absolute amounts. Thus, it is equally possible that the carbohydrate content of the diet could account for the diabetogenic effects. Studies are in progress in which the percentage content of carbohydrate, protein and fat is varied as a means of answering this question.

\section{Effect of acetohexamide}

As an additional step in the attempt to analyze the metabolic responsiveness of the sand rat, a study was carried out using the drug acetohexamide (Dymelor, Lilly) [12]. The experiment was done in the U.S. Naval Medical Research Unit \# 3 laboratories in Cairo, with animals recently captured in the desert. The drug was incorporated in the basic synthetic diet, which included $51 \%$ glucose, $23 \%$ protein and $3.5 \%$ fat. A striking difference was apparent between the effects of the diet in the two different groups (see Table 1). The animals

Table 1. Effect of acetohexamide (in diet $B$ ) on blood glucose and plasma insulin (mean values)

\begin{tabular}{llcc}
\hline & $\begin{array}{l}\text { Blood glucose } \\
\text { (mg\%) }\end{array}$ & $\begin{array}{c}\text { Plasma insulin } \\
\text { (microunits/ml) }\end{array}$ \\
\hline Diet & Control & $61(6)^{1}$ & $54(6)$ \\
A & $3 \mathrm{wk}$. & $214(2)$ & $914(2)$ \\
& $6 \mathrm{wk}$. & $153(2)$ & $745(2)$ \\
\hline Diet & Control & $65(5)$ & $38(5)$ \\
B & $3 \mathrm{wk}$. & $93(4)$ & $442(4)$ \\
& $6 \mathrm{wk}$. & $64(4)$ & $157(3)$
\end{tabular}

1 Figure in parentheses $=$ no. of animals.

fed the basic synthetic diet (diet A) had a high mortality, with only 2 of the 6 animals surviving for the full 6 weeks of the experiment. The survivors had markedly elevated "fasting" glucose levels and abnormal glucose tolerances. These changes were identical with a much larger number of animals previously studied in a similar fashion [7]. In contrast, the group of animals in which the basic diet was supplemented with acetohexamide (diet B) had only one animal die out of five, and maintained a normal "fasting" glucose level and a 
normal glucose tolerance. At the same time, the plasma insulin levels were markedly elevated in both groups. Although the number of animals is too small to permit statistical evaluation, it is clear that the insulin levels were at least no higher in the group on acetohexamide than in the animals on the basic diet.

Thus, acetohexamide seems to have a protective effect on sand rats on an otherwise "diabetogenic" diet; this beneficial effect occurs in the presence of plasma insulin levels that are lower - or, at least, no more than those seen in the non-treated group. 'This suggests the possibility of extra-pancreatic effects of the drug.

\section{Infections}

A striking finding in the sand rat has continued to be the high incidence of infections [9]. Pneumonia, and abscesses in jaws, skull and extremities are frequent. The jaw and skull abscesses may be secondary to abrasions of the gums, since acute gingivitis and periodontal abscesses are common (Fig. 3). Pyelonephritis

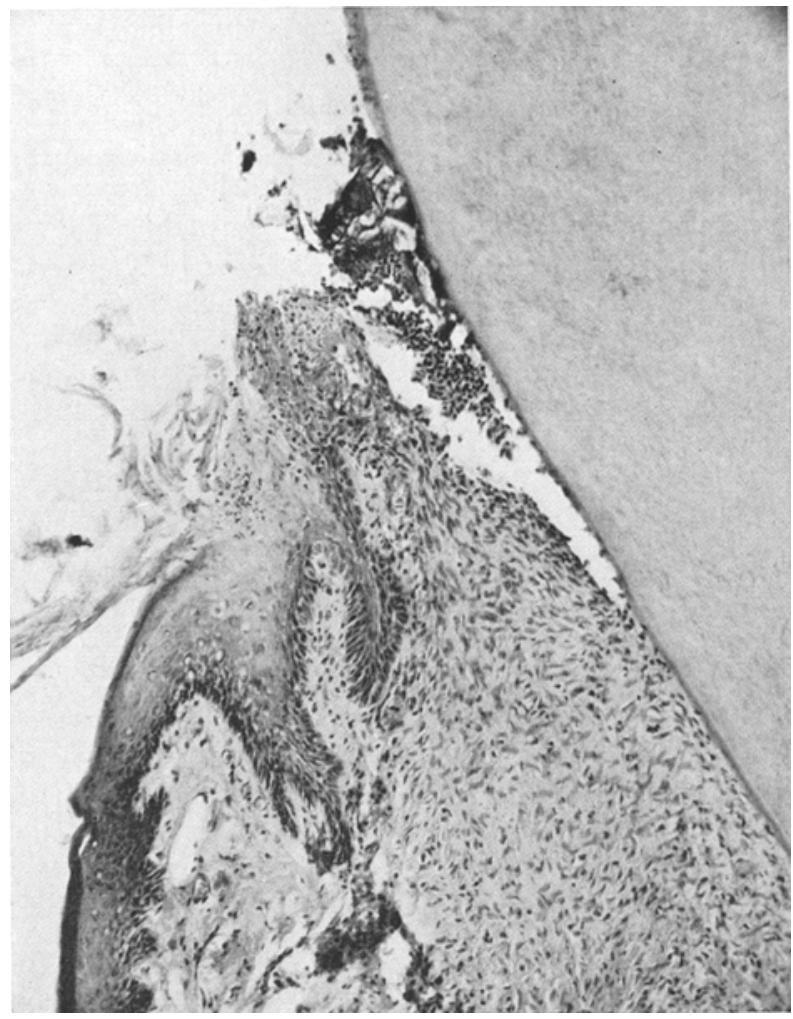

Fig. 3. Focus of acute gingivitis at dental margin. $120 \times$

was occasionally present, and in 3 instances the renal infection took the form of an acute necrotizing papillitis (Fig. 4) similar to the entity that is often seen in humans with diabetes mellitus. Sections of salivary glands were taken at autopsy of sand rats that died shortly after arrival from Egypt. Large cytomegalic intranuclear inclusions were seen in about $40 \%$ of these (Fig. 5); no inclusion bodies were seen in any other organs.
The incidence of these infections was not demonstrably greater in animals with manifest diabetes than in those apparently normal. It has been suggested,

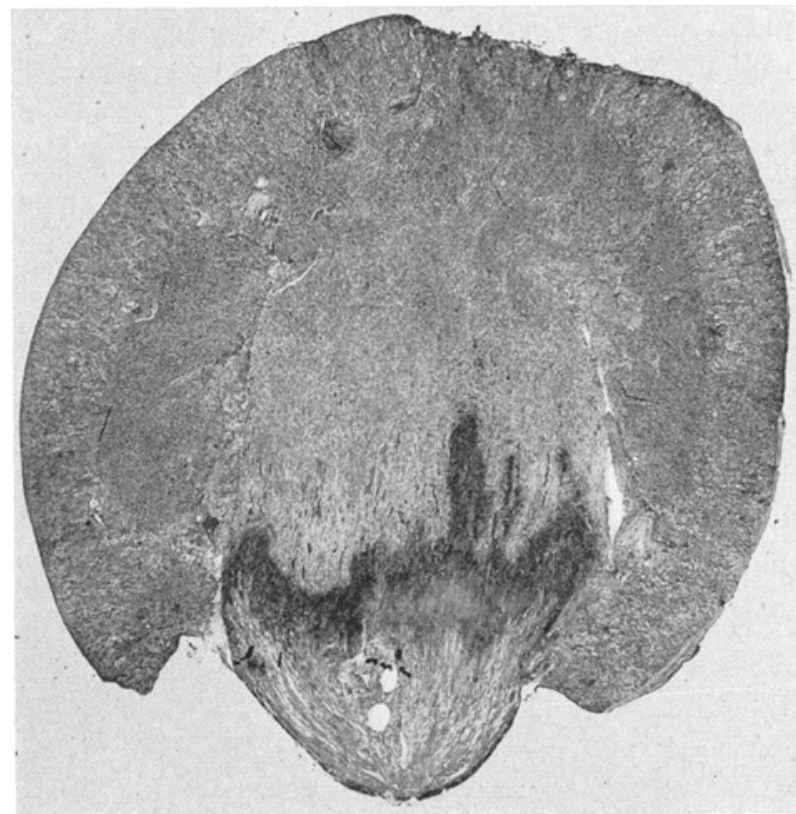

Fig. 4. Acute necrotizing renal papillitis. $10 \times$

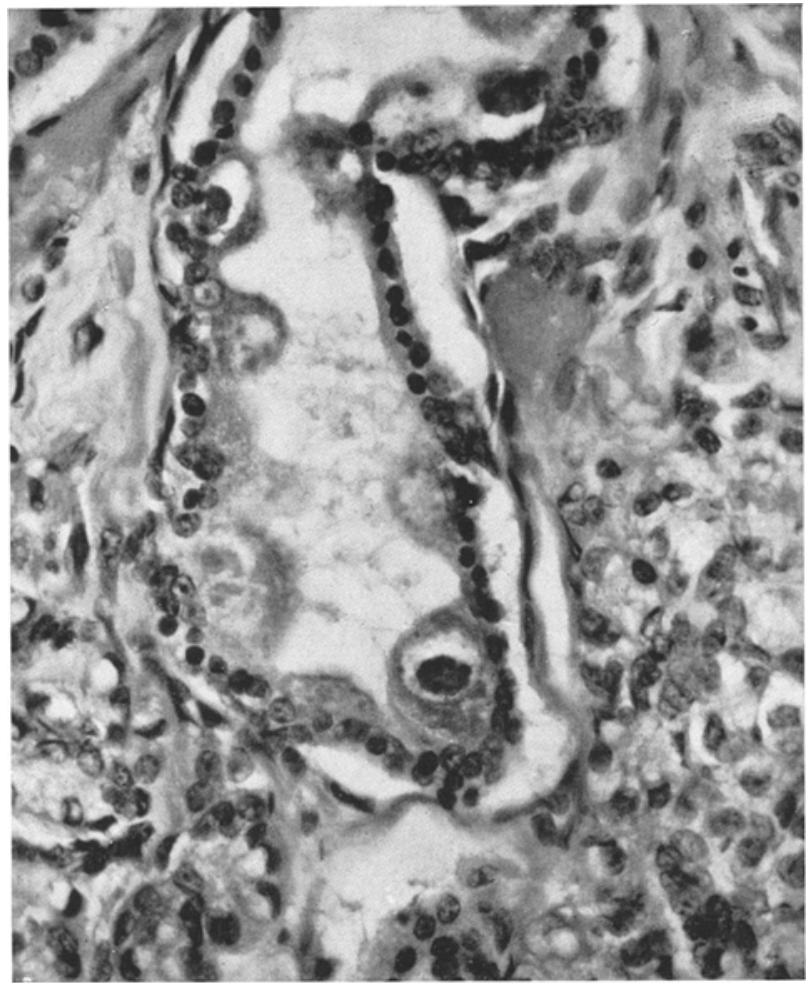
Fig. 5. Intranuclear cytomegalic inclusions in duct cells of salivary gland.
\[ 807 \times \]

since all sand rats seem to be predisposed to diabetes, that the high incidence of infections may reflect this generalized incipient diabetic state [9]. Additional 
suggestive evidence for this concept is the observation that an occasional sand rat developed some decrease in glucose tolerance even when on mixed vegetables, especially if beets were a major part of that diet; and that in some cases the decrease in glucose tolerance was transient and was associated with the appearance of a jaw abscess or other infection [7]. When the jaw abscess subsided the glucose tolerance returned to normal. This type of response during a period of stress may be similar to the cortisone-glucose tolerance test, which in humans has been used to unmask a latent diabetic state [5].

Response of sand rat adipose tissue to insulin in vitro

Because of the generally high plasma insulin levels in the sand rats on a diabetogenic diet, it is hypothesized that the resulting diabetes is related to a decreased peripheral effectiveness, rather than to an absolute deficiency of insulin. As one means of testing this possibility, a study was designed to evaluate the response of sand rat adipose tissue to insulin in vitro [11].

Three sand rats were maintained on mixed vegetables, and 6 sand rats were fed a synthetic "diabetogenic" diet for $3-8$ weeks. At the end of this time the effect of varying concentrations of pork insulin on glucose metabolism of epididymal fat tissue was studied. The oxidation of glucose-1-14 $\mathrm{C}$ to ${ }^{14} \mathrm{CO}_{2}$ was measured over a 2 -hour period of incubation. Control studies were done on the epididymal adipose tissue from Sprague-Dawley (Sp-D) strain laboratory rats.

The results are summarized in Fig. 6. Adipose tissue from fasted $\mathrm{Sp}-\mathrm{D}$ rats had a slightly higher

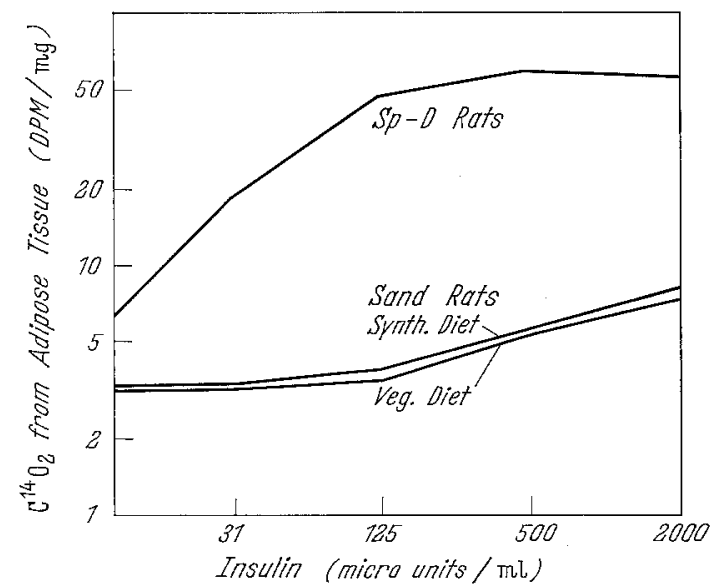

Fig. 6. ${ }^{14} \mathrm{CO}_{2}$ production by epididymal adipose tissue of Sprague-Dawley rats (Sp-D) or of sand rats (on either synthetic diet or vegetable diet)

resting level of glucose oxidation than tissues from fasted sand rats. In response to increasing concentrations of pork insulin the $\mathrm{Sp}-\mathrm{D}$ adipose tissue showed a marked increase in glucose oxidation. In contrast the sand rat adipose tissue increased its ${ }^{14} \mathrm{CO}_{2}$ production by a slight amount at only the highest concentrations of insulin. The effect was similarly small in all sand rats, whether they were on a "diabetogenic" diet or were fed vegetables.

Despite the unresponsiveness of sand rat adipose tissue to insulin it was found that administration in vivo of insulin resulted in hypoglycemia (Fig. 7). It is thus possible that insulin has an effect on the glucose utilization of some sand rat tissues-even if not on adipose tissue. It would be pertinent to carry out studies in vitro of the responsiveness of striated muscle to insulin.

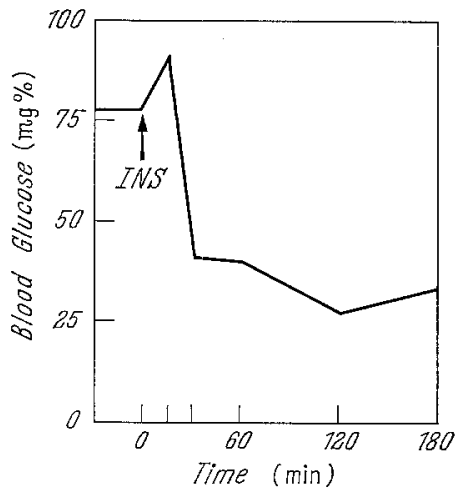

Fig. 7. Blood glucose changes in sand rat after intraperitoneal pork insulin, $1.0 \mathrm{unit} / \mathrm{kg}$

Acknowledgement. The authors would like to express their appreciation to Dr. Harry HoogstraAs and the staff at the U.S. Naval Medical Research Unit $\# 3$ in Cairo, Egypt for their kind assistance in some of these studies.

\section{References}

[1] Albertssen, V.: Diabetes in Iceland. Diabetes 2, 184-186 (1953).

[2] CAnilu, G.F.: Pathophysiology of diabetes. Med. Clin. N. Amer. 49, 881-892 (1965).

[3] Campbell, G.D.: Diabetes in Asians and Africans in and around Durban. S. Afr. med. J. 37, 1195-1208 (1963).

[4] CoHen, A.M.: Prevalence of diabetes among different ethnic Jewish groups in Israel. Metabolism 10, $50-58$ (1961).

[5] FaJans, S.S., and J.W. Cons: An approach to the prediction of diabetes mellitus by modification of the glucose tolerance test with cortisone. Diabetes $\mathbf{3}$, $296-304$ (1954).

[6] Hackel, D.B., H.E. Lebovitz, L.A. Frohman, E. MIKAT and K. SchMidT-NIELSEN : Effect of dietary caloric restriction on the glucose tolerance and plasma insulin of the sand rat. In Preparation.

[7] - L. Frohmax, E. Mrtát, H. E. Lebovitz, K. Schmidt-NIELSEN and T.D. KTNNEY: Effect of diet on the glucose tolerance and plasma insulin levels of the sand rat (Psammomys obesus). Diabetes 15, 105-114, (1966).

[8] - - - - Review of current studies on effect of diet on the glucose tolerance of the sand rat (Psammomys obesus). Ann. N.Y. Acad. Sei. 131, $459-463$ (1965).

[9] - K. Schmidt-NIELsen, H. B. Haines and E. Mikat : Diabetes mellitus in the sand rat (Psammomys obesus). Pathologic studies. Lab. Invest. 14, 200-207 (1965). 
[10] Haines, H.B., D.B. Hackel and K. SchmidtNIELSEN: Experimental diabetes mellitus induced by diet in the sand rat. Amer. J. Physiol, 208, 297 (1965).

[11] Horton, E.S., L.A. Fromman, H.E. Lebovitz, D.B. Hagkel and E. Mikat: Effect of insulin on glucose metabolism by sand rat (Psammomys obesus) adipose tissue in vitro. In Preparation.

[12] Mukat, E., D. B. HackeL, H. E. Lebovitz, K. SchMiDT-NIELSEN and T.D. KINNEY: The effect of acetohexamide treatment of sand rats on a 'diabetogenic' diet. In Preparation.

[13] Mrkr, E., A.A. Like, J.S. Somidner, J. STwinke and G.F. CAHILI: Acute ketotic type diabetic syndrome in sand rats with special reference to the pancreas. Diabetes 15, 749-760 (1966).

[14] NEEL, V.V.: Diabetes mellitus: a "thrifty" genotype rendered detrimental by "progress"? Amer.J. Human Genet. 14, 353-362 (1962).

[15] SChMtdd-Ntelser, K., H.B. HatNes and D.B. HaCKEL: Diabetes mellitus in the sand rat induced by standard laboratory diets. Science 143, 689-690 (1964).

Donald B. HaCkeL, M. D.

Department of Pathology

Duke University Medical Center

Durham, North Carolina, U.S.A. 